\title{
FIRST AND SECOND LANGUAGE CHILD SPEAKERS OF AFRIKAANS'S KNOWLEDGE OF FIGURATIVE LANGUAGE
}

Kristin van der Merwe \& Frenette Southwood Stellenbosch University

This article reports on a study that compared the knowledge of figurative language in first (L1) and second language (L2) speakers of Afrikaans, aged 8 to 10. To assess comprehension of figurative language, 25 idioms were initially presented without context; only if the child gave an incorrect interpretation was the idiom placed in context. There was no statistically significant difference between the comprehension of idioms by the two language groups and they gave comparable numbers of literal interpretations. Providing context was beneficial to both groups. In the simile completion task, the child had to give the last word of a simile read to him by the researcher. This proved easier for both groups than the idiom task, but still no significant differences were found between the two groups. The results imply that the extent to which a child is aware of the existence of figurative language (i.e., that what is said is not always what is meant) possibly has a greater influence on his/her figurative language skills than does the amount of exposure to figurative language used by others. This implies that an awareness of figurative language as well as the specific meaning of idioms and similes needs to be taught explicitly, regardless of whether the child is an L1 or L2 learner.

Keywords: figurative language, child speakers, comprehension and production of figurative language, knowledge of idioms

\section{INTRODUCTION}

The comprehension and production of figurative language incorporates several domains related to the pragmatics of language. It reflects a child's world knowledge and the application thereof (Gordon, 1961; Hoffman \& Honeck, 1980: 7): It requires the ability to make inferences in processing semantic and contextual information by decoding implications (Gordon, 1961; Hoffman \& Honeck, 1980: 7); the recognition of speaker intention (see. Gibbs, 1987: 569-570); and metalinguistic awareness, specifically the ability to make judgments about multiple levels of meaning (see, for example, Nelson, 1998: 483).

Idioms and similes are often the first two categories of figurative expressions which a child encounters and learns (Malgady, 1977: 1734; see Owens, 2001: 375-378 for an overview of the development of figurative language skills in children). Idioms are defined as familiar, fixed expressions in which meaning is not dependent on the literal interpretation of the individual words (Zempleni, Haverkort, Renken \& Stowe, 2007: 1). It has been proposed that idioms are stored in the mental lexicon as large single units and then retrieved much like individual words are (Ackerman, 1982; see also Burbules, Schraw \& Trathen, 1989: 93). The semantic analysability of an idiom has proved to be of importance for both adults and children 
in idiom comprehension, and takes precedence over the syntactic form of the expression (Wasow, Sag \& Nunberg, 1983; Gibbs, Nayak \& Cutting, 1989; Cacciari \& Glucksberg, 1991; Gibbs, 1991: 614; Gibbs \& Nayak, 1991). Similes are significantly easier to comprehend than other forms of figurative language, including idioms, due to similes' greater linguistic explicitness and obvious referential domains (Reynolds \& Ortony, 1980; Seidenberg \& Bernstein, 1986; Pretorius, 1989: 22).

Various theoretical explanations have been proposed for the comprehension processes pertaining to figurative language in both adults and children, such as the standard pragmatic model (Grice, 1975), direct-access view (Gibbs, 1994, 2002), graded salience hypothesis (Giora, 1997, 2002), and constraint satisfaction model (Katz \& Ferretti, 2001). It has been proposed that children's comprehension of figurative language differs from that of adults in that children (1) have an amplified need for and reliance on context (see Levorato, Nesi \& Cacciari, 1992; Cain, Oakhill, Barnes \& Byrant, 2001); (2) lack ontological knowledge and general life experiences, and possess a smaller vocabulary; (3) have a tendency for literal interpretations; and (4) fare better at comprehending figurative language than producing it (Gibbs, 1987, 1991; Vosniadou, 1987; Nippold \& Martin, 1989; Levorato \& Cacciari, 1995).

The two most salient processing strategies developing minds have at their disposal are interpretation of context and semantic analysis (Cain et al., 2001: 857). Idiom comprehension, therefore, involves both top-down contextual processing and bottom-up semantic processing (Nippold, Moran \& Schwarz, 2001). Levorato and Cacciari (1999) studied idiom comprehension in children between the ages of 7 and 9 years in order to compare these two processing strategies. They concluded that younger children were more reliant on context to achieve the meaning of novel words, whereas older children were more able to use semantic analysis although they also benefited from context. In the case of younger children, semantic analysis led to more literal interpretations.

There is a strong relationship between children's cognitive abilities and their comprehension of figurative language. Douglas and Peel (1979: 116) found that children between the ages of 3 and 7 were unable to override literal interpretations but, as from the age of 8 years, children displayed the onset of an ability to interpret words as having dual meanings. Twelve-year-old children showed a clear ability to interpret words with more than one meaning, such as cold and warm, which denote temperatures but also personality temperaments (Douglas \& Peel, 1979: 116; see also Nippold, 1991; Abkarian, Jones \& West, 1992; Levorato \& Cacciari, 1999). Levorato and Cacciari's (1995) Global Elaboration Model (GEM) focuses on the finding that figurative language is acquired on the basis of processes underlying lexical, semantic, and cognitive developments. The main questions addressed by the GEM are, firstly, when and how a child first escapes a literal interpretation and seeks a more coherent, global interpretation and, secondly, what linguistic and cognitive abilities are needed in order to facilitate this process (Levorato \& Cacciari, 1999). Levorato and Cacciari propose the following criteria as facilitators for the comprehension of figurative language: (1) an understanding of the domain being discussed and therefore the semantic domain as well; (2) the ability to use contextual information as well as integrate different sources of information; and (3) an awareness that what is said is not always what is meant. Furthermore, a high positive correlation has been found between figurative language comprehension and reading ability (Cain \& Oakhill, 1999; Cain et al., 2001; Nippold et al., 2001; Levorato, Nesi \& Cacciari, 2004; Cain, Oakhill \& Lemmon, 2005). 
Figurative language competence of second language (L2) learners, particularly child L2 speakers, has been given little attention compared to acquisition of grammar by L2 learners. Experimental studies and theories of figurative language processing and use by L2 speakers remain relatively scarce (Manno, 1998; Cooper, 1999; Durgunoglu \& Öney, 2000; Martinez, 2003). The evaluation of figurative language competence is often viewed as a peripheral study of L2 acquisition and is often only deemed worth exploring once a certain level of proficiency and cognitive maturity has been attained; hence, most research is done with adults and not children (Durgunoglu \& Öney, 2000; Laufer, 2000: 186; Hashemian \& Nezhad, 2006: 42). Furthermore, most studies on figurative language in bilinguals focused on structurally and semantically dissimilar languages.

Cooper (1999) investigated the processing strategies employed by L2 speakers during idiom processing. The adult participants in Cooper's study were requested to give constant feedback in response to the idioms. Cooper (1999: 243) identified the strategies employed by the L2 speakers as repetition or paraphrasing, discussing, analysing or requesting information, guessing with reference to context, using the literal to aid interpretation correctly, using background knowledge, and referring to an idiom in their first language (L1). Another strategy was to recall an incident or situation experienced by the individual to which the idiom may have been relevant. Cooper (1999) found that guessing with reference to context was the most frequently used strategy; discussing and analysing was the second most employed strategy, and using the literal meanings to interpret idioms was also common.

In general, there is little information on the development of advanced language skills by typically developing monolingual children, and even less so for child L2 speakers. This is especially the case for speakers of languages other than English. This study aimed to contribute to the limited body of knowledge on one type of advanced language skill, namely the ability to comprehend and use figurative language. Specifically, the study examined the comprehension of Afrikaans idioms and the completion of Afrikaans similes in two groups of children between the ages of 8 and 10 years. The participants included typically developing boys whose L1 is Afrikaans and typically developing English-speaking boys whose L2 is Afrikaans. The hypotheses for this study were the following (the first three hypotheses took into account the descriptions of abilities provided by the GEM for children aged 8 to 12 years, for instance that sensitivity towards context develops from 8 years onwards):

Hypothesis 1: The L1 speakers will fare better than the L2 speakers in the idiom task, seeing that the L1 speakers should have had more exposure to Afrikaans idioms than the L2 speakers.

Hypothesis 2: Whereas it could be anticipated that, for both the L1 and the L2 group, the comprehension of idioms would improve with age, the age range of the participants in the present study was not particularly wide, possibly not allowing for clearly noticeable differences between age groups. Therefore, it was hypothesised that reading ability (rather than age) will be a reliable indicator of the ability to comprehend idioms.

Hypothesis 3: Context will play an important role in the comprehension of idioms for both groups of participants.

Hypothesis 4: The L1 speakers will fare better than the L2 speakers in the simile task, despite the explicitness of similes which makes them more decomposable than idioms; it was 
expected that the L1 speakers would have had more exposure to Afrikaans similes (and a larger Afrikaans vocabulary) than the L2 speakers.

\section{METHODOLOGY}

\section{Design of the study}

This study formed part of a larger project on young school-going children's knowledge of figurative language. In the larger project, children with specific language impairment were also included. Even though the results obtained from these children are not included here, the fact that they acted as participants in the larger project influenced the present study in two ways. Firstly, it proved difficult to find suitable participants with specific language impairment; despite intense efforts, only six could be obtained. This meant that the number of participants in the typically developing (L1 and L2) groups were also limited to six each: participants in the three groups were paired according to (1) school grade, as far as possible; (2) reading ability, as assessed by their class teacher; and (3) age, as these three variables have been found to influence knowledge of figurative language (see, for example, Cain \& Oakhill 1999; Levorato et. al., 2004). Because of the size of the sample, the present study should be viewed as an exploratory one. Secondly, the statistical values (i.e., F- and p-values) reported in the present study were those obtained when comparing the performance of all three groups, but this did not influence the deductions and conclusions of the present study in any way.

In the present study, the knowledge of figurative language by two groups of 8- to 10-year-old boys was assessed and compared. Children of 8 to 10 years were selected as participants, as, according to the GEM, a sensitivity for context develops between the ages of 8 and 9 , and an awareness that meaning can be conveyed both literally or figuratively starts to develop at age 10 , as do the ability to consider the internal state of the speaker in order to understand his/her intentions.

\section{Participants}

Five mainstream dual medium primary schools were approached and approximately 110 letters (with information on the study) and consent forms were sent to parents via the class teachers. Seventy of the 110 forms were returned, with 10 parents withholding consent. However, several of the returned forms proved to be from unsuitable participants; some were the wrong age or gender, whereas others were not appropriate matches in terms of their reading marks.

Table 1 presents information on the 12 participants. The first three letters of the participant codes represent their mother tongue: AFR for Afrikaans-speaking (L1) and ENG for Englishspeaking (with Afrikaans as L2). The numbers following the three letters indicate the age of the participant in years; and the letters $\mathrm{A}, \mathrm{B}$, and $\mathrm{C}$ differentiate between the participants where there was more than one participant in that age group. 
Table 1: Information on participants, ordered according to their L1

\begin{tabular}{|c|c|c|c|c|c|}
\hline $\begin{array}{l}\text { Participant } \\
\text { code }\end{array}$ & Age & $\begin{array}{l}\text { School } \\
\text { grade }\end{array}$ & $\begin{array}{l}\text { Reading level } \\
\text { Afrikaans }^{\mathrm{a}}\end{array}$ & $\begin{array}{l}\text { Reading level } \\
\text { English }\end{array}$ & L1 \\
\hline AFR8A & $8: 3$ & 2 & 3 & Not known & Afrikaans \\
\hline AFR9A & $9: 4$ & 3 & $2+$ & Not known & Afrikaans \\
\hline AFR9B & $9: 5$ & 2 & $2+$ & Not known & Afrikaans \\
\hline AFR9C & $9: 9$ & 3 & 2 & Not known & Afrikaans \\
\hline AFR10A & $10: 2$ & 4 & 3 & Not known & Afrikaans \\
\hline AFR10B & $10: 3$ & 4 & 2 & Not known & Afrikaans \\
\hline ENG8A & $8: 3$ & 2 & 3 & 3 & English \\
\hline ENG9A & $9: 3$ & 3 & $2+$ & 3 & English \\
\hline ENG9B & $9: 3$ & 3 & $2+$ & $2+$ & English \\
\hline ENG9C & $9: 9$ & 3 & 2 & 3 & English \& German \\
\hline ENG10A & $10: 3$ & 4 & 3 & 3 & English \\
\hline ENG10B & $10: 4$ & 4 & 2 & 3 & English \\
\hline
\end{tabular}

a $1=1-34 \%$ (Not achieved); $2=35-49 \%$ (Partially achieved); $3=50-69 \%$ (Satisfactory); $4=$ 70-100\% (Outstanding).

\section{Experimental tasks}

Two tasks were administered, one on idioms and another on similes. These tasks were adapted from Die Afrikaanse Semantiese Taalevalueringsmedium (AST; Pretorius, 1989), which was compiled to test children at foundation and intermediate school level on various aspects of Afrikaans grammar and general language skills. Idioms, metaphors, and proverbs are classified under one category in the AST. Although idioms, similes, and proverbs are all defined differently, they are all essentially metaphoric in nature, particularly in instances where the individual is unfamiliar with expressions (Gibbs, Bogdanovich, Sykes \& Barr, 1997: 141).

The AST contains 25 idioms, varying in degree of difficulty. For the purposes of the present study, language contexts were designed by the researcher for these idioms. The AST's idioms were first presented without context and, if a participant could not accurately relay the meaning of the idiom, the idiom was then presented in context. For example, if a participant could not provide the correct meaning of Hang aan iemand se lippe, the researcher represented the idiom as Die juffrou lees 'n baie opwindende storie vir die kinders en hulle hang aan haar lippe. Refer to the appendix for the list of idioms used in the present study, in their order of presentation.

The simile task comprised the 25 similes of the AST (see appendix). This task entailed that incomplete sentences were read to the child by the researcher; the child was then required to fill in the missing word. For example, the researcher read Iets is so groen soos... and the child was expected to respond with a one-word answer such as gras.

\section{Data collection procedure}

The parents of suitable participants were contacted in order to schedule single individual appointments with their children. Data collection took place after school hours, so as to not disrupt classroom activities. Only the first author and the child were present during the sessions. Parents were given the option of being present; however, all declined. Sessions were 
approximately 30 minutes long. The L2 participants often took slightly longer (up to 40 minutes) because the researcher had to translate the items into English after they had first been read in Afrikaans.

Prior to administering the tasks, a brief discussion took place on the notion of figurative language, accompanied by examples. The participants were then asked if they knew what an idiom was. Only participant AFR10A gave a correct answer. Of the 12 participants, he was the most advanced in terms of age, grade, and reading mark, and had covered some idioms in the Grade 4 syllabus. Participants were then asked to give the meaning of the idiom Sy is deur die blare. This idiom is opaque or, to use the terminology of Gibbs (1991: 613), semantically nondecomposable, meaning that the words in the idiom reveal very little from which to draw a figurative analogy. Nondecomposable idioms are the most abstract of idioms (Gibbs 1991: 614), and are therefore difficult to comprehend without context. Because the intention was to train the participants in the task of listening and commenting on idioms first without and then with context, an idiom that was highly likely to require context before the participants would comprehend it, was selected as training material.

Where correct answers to Sy is deur die blare were not given, the idiom was presented in context and participants were prompted with questions until they arrived at a correct answer and it was clear that they had understood the task. The researcher then explained that an idiom should not be taken literally; rather, it is 'all about ideas'. For the English-speaking children, the instructions and context of the idiom were given in English, with only the idiom Sy is deur die blare given in Afrikaans.

The participants were then told that they would be read a sentence which they had to explain. Participants were assured that their answers could not be wrong; they should merely say what they thought the sentence means. They were also told that, in some instances, they would be told a short story in which the idiom was placed in context, and they would then be asked to respond to that. The L2 participants were furthermore asked to translate the idioms and their contexts, to verify whether the sentences had been understood - if not, the sentences were translated into English by the researcher.

All sessions were tape-recorded with the permission of the child and parent. All participants completed both tasks and co-operated well throughout the session. In most cases, participants appeared engaged with the researcher and the tasks at hand.

\section{Scoring of responses}

For the idiom task, scoring was based on categories proposed by Nippold (1991: 103) and used by Cain et al. (2005). These categories are given below and are exemplified by actual responses given by the participants. The idiom in question was Ek is nie onder ' $n$ kalkoen uitgebroei nie.

Correct answer: $\quad$ Ek is nie stupid nie.

Related answer: $\quad$ Ek lyk nie so simpel soos 'n turkey nie.

Restatement: $\quad$ 'n Kalkoen het my nie in 'n eier gelê nie.

Unrelated answer: Jy kom nie uit 'n kalkoen nie, jy kom uit 'n hoender uit. 'n Hoender broei jou uit, dan is jy net ' $n$ kleintjie, dan raak jy net so groot soos hy.

Literal interpretation: Ek is uit my ma se maag uitgebroei.

No response: $\quad$ Ek weet nie. 
The idiom task was tallied out of a total of 50, including both the 25 decontextualised idioms and the 25 idioms presented in context. In instances where participants gave the correct answer for the decontextualised idiom and where the context was therefore not needed, the participant was awarded two points.

Only those similes which were completed correctly were given a mark. For instance, in the case of So glad soos ..., only seep was accepted as a correct answer and not other plausible ones such as 'n eierdop, plastiek, or slippery rocks.

\section{RESULTS}

\section{Idioms}

The raw scores depicted in Table 2 indicate that the best performers, in general, were the Afrikaans L1 speakers; they outperformed the L2 group in five out of the six cases. The mean score of the L1 group was 21/50; the L2 group had a mean score of $15 / 50$. However, the Kruskal-Wallis test showed that this difference between the two groups was not statistically significant; $F_{2,15}=3.3060, p=.06$.

As can be seen from Table 2, participant ENG9C fared best out of the six L2 participants in the idioms task, achieving a score of 26/50. This result was unexpected, given the participant's low Afrikaans reading mark. In general, the L1 participants' scores appear to increase with an increase in reading mark; this was not the case for the L2 group. Participants ENG8A and ENG9B fared worst in the idioms task. Participant ENG8A had an Afrikaans reading mark of 3 , which theoretically should have resulted in a higher score achieved in the task, but he was not sufficiently bilingual to translate or understand the items. Nor was participant ENG10B able to translate or understand Afrikaans sufficiently for the task to be carried out solely in Afrikaans; large portions of the tasks were translated into English by the researcher for both ENG8A and ENG10B. There was no clear developmental trend, i.e., scores did not clearly increase with age in either of the two groups.

Table 2: Raw scores for correct and related responses to the idioms task

\begin{tabular}{|l|l|l|l|l|}
\hline Reading mark & L1 participants & Idioms (max 50) & L2 participants & Idioms (max 50) \\
\hline 3 & AFR8A & 19 & ENG8A & 9 \\
\hline $2+$ & AFR9B & 25 & ENG9A & 15 \\
\hline $2+$ & AFR9B & 21 & ENG9B & 9 \\
\hline 2 & AFR9C & 16 & ENG9C & 26 \\
\hline 3 & AFR10A & 30 & ENG10A & 19 \\
\hline 2 & AFR10B & 16 & ENG10B & 13 \\
\hline & Mean score & 21 & Mean score & 15 \\
\hline
\end{tabular}


The role of context in the comprehension of the idioms

To examine the role played by context, scores were compared between the correct answers for the decontextualised idioms and for the idioms placed in context. The results, shown in Table 3 , indicate that context aided all participants to some degree. Even though the mean scores for decontextualised idioms showed that the L1 group outperformed the L2 group (7/25 for the L1 group; 5/25 for the L2 group), the Kruskal-Wallis test showed that this difference in mean score was not statistically significant $\left(\mathrm{F}_{2,15}=3.1508, \mathrm{p}=.07\right)$. For idioms placed in context, the L1 group achieved the highest score, 10/25, compared to the 8/25 of the L2 group. The Kruskal-Wallis test again indicated that this difference was not statistically significant $\left(\mathrm{F}_{2,15}=1.3808, \mathrm{p}=.28\right)$.

Table 3: Raw scores of correct responses (excluding related responses) to decontextualised idioms and idioms placed in context

\begin{tabular}{|l|l|l|l|l|l|l|l|}
\hline $\begin{array}{l}\text { Reading } \\
\text { mark }\end{array}$ & \multirow{2}{*}{$\begin{array}{l}\text { L1 parti- } \\
\text { cipants }\end{array}$} & $\begin{array}{l}\text { Decontextu- } \\
\text { alised idioms }\end{array}$ & $\begin{array}{l}\text { Idioms in } \\
\text { context }\end{array}$ & $\begin{array}{l}\text { L2 parti- } \\
\text { cipants }\end{array}$ & $\begin{array}{l}\text { Decontextu- } \\
\text { alised idioms }\end{array}$ & $\begin{array}{l}\text { Idioms in } \\
\text { context }\end{array}$ \\
\cline { 3 - 4 } & & $\begin{array}{l}\text { Combination of these } \\
\text { two scores is score /50 }\end{array}$ & & \multirow{2}{*}{$\begin{array}{l}\text { Combination of these } \\
\text { two scores is score /50 }\end{array}$} \\
\hline 3 & AFR8A & 2 & 8 & ENG8A & 0 & 6 \\
\hline $2+$ & AFR9B & 7 & 15 & ENG9A & 4 & 8 \\
\hline $2+$ & AFR9B & 2 & 13 & ENG9B & 2 & 3 \\
\hline 2 & AFR9C & 4 & 9 & ENG9C & 10 & 12 \\
\hline 3 & AFR10A & 18 & 11 & ENG10A & 8 & 10 \\
\hline 2 & AFR10B & 6 & 6 & ENG10B & 4 & 6 \\
\hline & $\begin{array}{l}\text { Mean } \\
\text { Score }\end{array}$ & 7 & 10 & $\begin{array}{l}\text { Mean } \\
\text { score }\end{array}$ & 5 & 8 \\
\hline
\end{tabular}

Again, as can also be seen from Figure 1, participant ENG9C was an anomaly. He outperformed his matched peer as well as all other participants in his group and most of the L1 participants. From Figure 2, it can be seen that context improved the scores of the participants.

Figure 1: Bar chart illustrating scores achieved in decontextualised idioms task

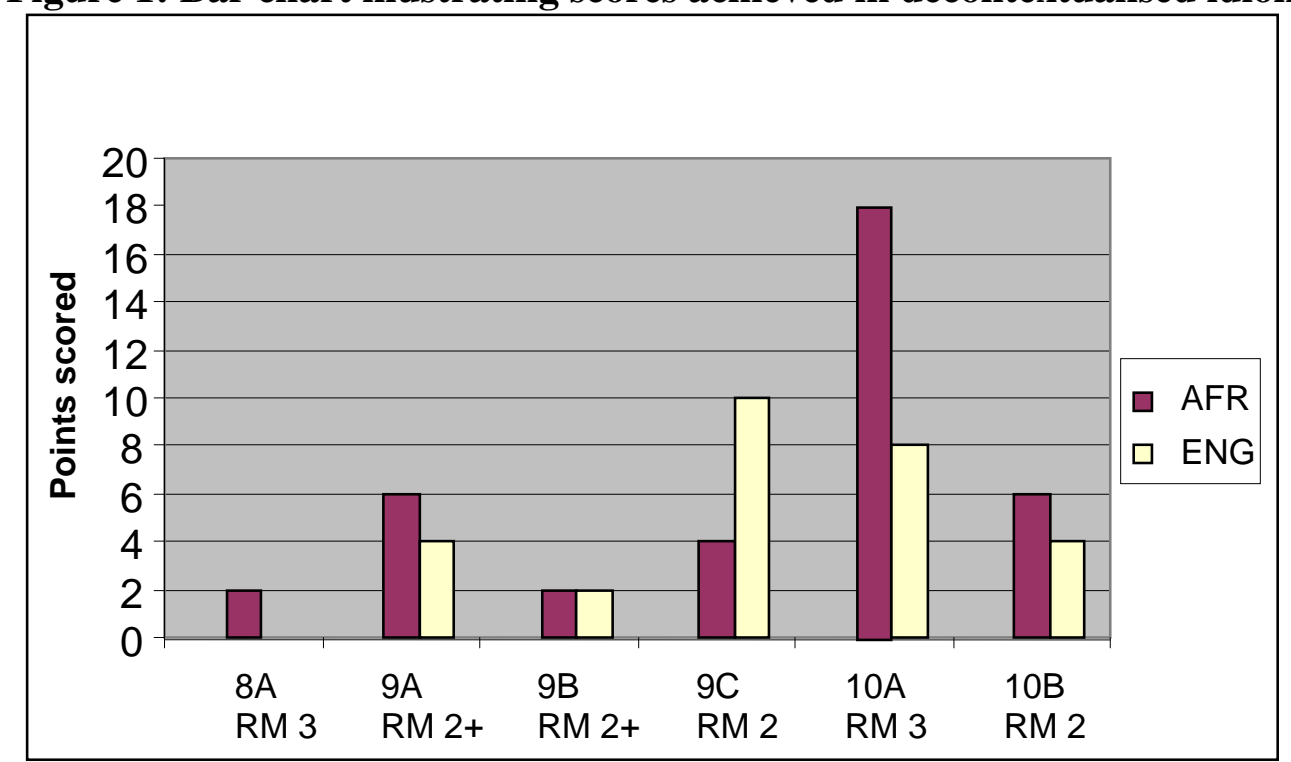




\section{Figure 2: Bar chart illustrating scores achieved in idioms in context task}

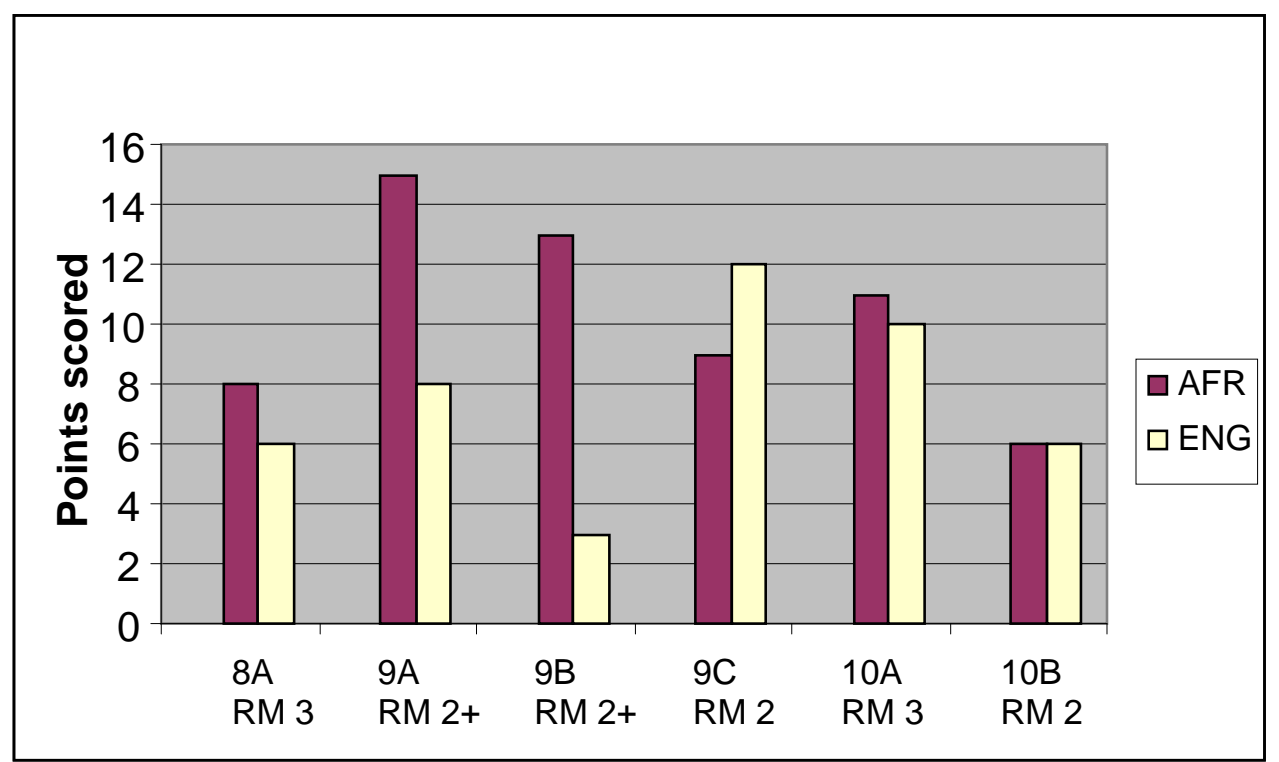

\section{Literal interpretation of the idioms}

Table 4 shows the number of literal answers supplied by the participants in both decontextualised idioms and idioms placed in context. Regarding decontextualised idioms, the mean score achieved by the L1 group was $5 / 25$ and that of the L2 group 6/25. The KruskalWallis test indicated that this difference was not significant $\left(\mathrm{F}_{2,15}=1.7954, \mathrm{p}=.20\right)$. The mean scores for the literal interpretations of idioms placed in context again only differ fractionally from one another. The L1 group scored the lowest (1/25), which was anticipated; the L2 group obtained a mean score of $3 / 25$. The Kruskal-Wallis test indicated this difference to be statistically nonsignificant $\left(\mathrm{F}_{2,15}=1.1975, \mathrm{p}=.33\right)$. For both groups, fewer literal interpretations were given when the idioms were placed in context, compared to the higher scores of literal interpretations of decontextualised idioms - again indicating that context aided the participants. The number of literal answers generally appeared to decrease with an increase in age, with the 10-year-old groups providing the fewest literal interpretations.

Table 4: Raw scores of literal answers to idioms

\begin{tabular}{|l|l|l|l|l|l|l|}
\hline $\begin{array}{l}\text { Reading } \\
\text { mark }\end{array}$ & $\begin{array}{l}\text { L1 parti- } \\
\text { cipants }\end{array}$ & $\begin{array}{l}\text { Decontextua- } \\
\text { lised idioms }\end{array}$ & $\begin{array}{l}\text { Idioms in } \\
\text { context }\end{array}$ & $\begin{array}{l}\text { L2 parti- } \\
\text { cipants }\end{array}$ & $\begin{array}{l}\text { Decontextua- } \\
\text { lised idioms }\end{array}$ & $\begin{array}{l}\text { Idioms in } \\
\text { context }\end{array}$ \\
\hline 3 & AFR8A & 7 & 2 & ENG8A & 7 & 4 \\
\hline $2+$ & AFR9A & 5 & 3 & ENG9A & 7 & 7 \\
\hline $2+$ & AFR9B & 8 & 1 & ENG9B & 5 & 4 \\
\hline 2 & AFR9C & 5 & 1 & ENG9C & 7 & 3 \\
\hline 3 & AFR10A & 2 & 0 & ENG10A & 4 & 0 \\
\hline 2 & AFR10B & 4 & 1 & ENG10B & 3 & 1 \\
\hline & $\begin{array}{l}\text { Mean } \\
\text { score }\end{array}$ & 5 & 1 & $\begin{array}{l}\text { Mean } \\
\text { score }\end{array}$ & 6 & 3 \\
\hline
\end{tabular}

Semantic decomposability of the idioms for the L1 and L2 speakers

The extent to which the participants experienced the idioms as semantically decomposable or nondecomposable was examined. An idiom was taken to be semantically decomposable if four of the six participants in a group had provided a correct answer. A context was taken to be exceptionally decomposable if all six participants had supplied a correct answer. Similarly, 
nondecomposable and exceptionally nondecomposable idioms were identified according to the number of participants who gave either no response or an unrelated response. Restatements were not considered as a reflection of nondecomposability; participants who restated the question were prompted, and if they did not elaborate further, their response was considered a literal interpretation. Literal interpretations were also tallied in the same manner as the decomposable and nondecomposable idioms.

The L2 group, but not the L1 group, found the following decontextualised idioms to be nondecomposable, with some of the responses by the L2 participants - where any were given - provided in brackets:

(1) Die hele dorp was in rep en roer ('The whole town was - ')

(2) Hulle bak en brou net soos hulle wil ('They can bake as much as they like')

(3) Agteros kom ook in die kraal

(4) Sy draai almal om haar vinger ('It means she was cross'; 'She does everyone up. She doesn't like anybody'; 'She thinks she is cool')

(5) Iemand oor die kole haal ('Someone stole the coals'; 'Taking someone off the coals. The person is in charge')

(6) Slaan die spyker op die kop ('Be careful of the nail'; 'Stop being naughty')

(7) Ek is nie onder 'n kalkoen uitgebroei nie ('I'm not born from a turkey. I don't look like a turkey'; 'You are not born out of an egg'; 'I'm not fat or anything').

Both groups found the following decontextualised idioms to be exceptionally nondecomposable, meaning that not one participant could provide the correct meaning of these idioms out of context. Again, some of the responses of the L2 participants - where any were made - are provided:

(1) Hy is in sy noppies

(2) 'n Appeltjie met iemand te skil hê ('An apple with somebody's skull')

(3) Sy skiet met spek ('She shoots with bacon')

(4) ' $n$ Kat in die sak koop ('To buy a cat in the bag. It means to do the right thing because you buy a cat in the bag'; 'A cat in the bag. When I go to the pet shop and I want a cat, the cat is in the bag')

(5) Iets van die hand sit

(6) Lekker is maar 'n vinger lank ('Liquorish'; 'A sweet is a finger long'; 'Something nice is as long as your finger. If you doing something nice, it is not very long, but the things you don't like are usually longer')

(7) Die huis staan in ligte laaie ('The house is lit by the light, no lights or candles, only the sun'; 'It means there is lots of light in it'; 'The house stands in empty draws. It was boring').

Only the L2 participants found the following decontextualised idioms extremely nondecomposable:

(1) Slaan voet in die wind ('The foot is sleeping in the wind'; 'Hurry up')

(2) Die koeël is deur die kerk ('The bullet is passed the church. Church is over quickly'; 'The bullet went through the church means that it went inside the church then went outside the church')

(3) Hy het die hasepad gekies ('He chose the rabbit's path'; 'He chose the greatest path'). 
No decontextualised idiom had correct answers given by four or more participants in any of the two groups. This means that none of the 25 decontextualised idioms were decomposable for the L1 or the L2 participants. When context was provided, the L1 participants found Hy in sy noppies and Bak en brou soos julle wil to be decomposable. The L2 participants also found Bak en brou soos julle wil decomposable once the context had been provided. They, but not the L1 participants, furthermore found Iemand oor die kole haal in context decomposable. When placed in context, the following idioms were exceptionally decomposable for both groups: (1) Geld groei nie op my rug nie; (2) Sy skiet met spek; (3) Slaan voet in die wind; (4) Die koeël is deur die kerk; (5) Staan in ligte laaie; and (6) Hang aan iemand se lippe.

The L1 group but not the L2 group tended to interpret Hy is ' $n$ bobbejaan (without context) literally. Here, the L2 group fared better, some providing interpretations such as 'It means that someone is silly' and 'He has gone crazy', although some did provide more literal interpretations such as 'I think it means that you can swing around trees'. Both groups interpreted the following three idioms without context literally to a very great extent:

(1) Ek kan slange vang ('I can catch a snake with like a net or - '; 'I can catch snakes. It means you are very good at it')

(2) Ons ry met Jan Tuisbly se karretjie ('We ride with Jan Tuis's little car'; 'We ride with his car'; 'We ride on ... I never knew that name')

(3) Hy eet alles vir soetkoek op ('He eats everything that is sweet cake'; 'He ate everything up. There was nothing left for the others').

\section{Similes}

As can be seen in Table 5, there were more marked differences between the scores achieved in the idioms task than in the simile task.

Table 5: Raw scores achieved by participants in the simile task

\begin{tabular}{|l|l|l|l|l|}
\hline Reading mark & L1 participants & Similes (max 25) & L2 participants & Similes (max 25) \\
\hline 3 & AFR8A & 7 & ENG8A & 3 \\
\hline $2+$ & AFR9B & 7 & ENG9A & 8 \\
\hline $2+$ & AFR9B & 4 & ENG9B & 3 \\
\hline 2 & AFR9C & 8 & ENG9C & 6 \\
\hline 3 & AFR10A & 9 & ENG10A & 7 \\
\hline 2 & AFR10B & 5 & ENG10B & 6 \\
\hline & Mean score & 7 & Mean score & 6 \\
\hline
\end{tabular}

For simile completion, the mean score of the L1 group was 7/25 and that of the L2 group $6 / 25$. The Kruskal-Wallis test indicated that this difference was not statistically significant $\left(\mathrm{F}_{2,15}=1.9675, \mathrm{p}=.17\right)$.

\section{DISCUSSION}

The first hypothesis, namely that the L1 speakers will fare better than the L2 speakers on the idiom task, was not borne out by the data. The L2 group's mean score on the idioms test was indeed lower than that of the L1 group, but the difference in scores between the two groups was not statistically significant. Those Afrikaans idioms which were semantically and/or syntactically very similar to their English counterparts - such as As die kat weg is, is die muis 
baas and Sy draai almal om haar vinger - were not experienced by the L2 speakers as being more decomposable than those which were dissimilar.

The second hypothesis, namely that reading ability will be a better indicator of performance than age would, was only partly borne out by the data: the scores of the L1, but not the L2, participants appeared to increase with an increase in reading level. Developmental trends (in terms of age) were only seen in the case of literal interpretations: in general, both the L1 and L2 participants gave fewer literal interpretations as their age increased. It could be that this general lack of developmental trends (in terms of both reading level and age) was due to the small sample size.

The third hypothesis predicted that context will play an important role in the comprehension of idioms. Context did indeed benefit both groups - in accordance with the GEM (Levorato \& Cacciari, 1995), according to which a sensitivity for context develops between the ages of 8 and 9 years. Younger children are said to be more reliant on context in figurative language interpretation than on the information they are able to obtain from a semantic analysis. Even though some researchers found semantic transparency and analysability aid correct interpretation (Gibbs, 1987; Nippold \& Taylor, 2002), others reported that semantic analyses lead to literal interpretations (Cain et. al., 2001; Levorato \& Cacciari, 1999). The L2 participants in the present study frequently gave literal interpretations of the Afrikaans idioms that were linguistically equivalent or similar to their English counterparts.

The fourth hypothesis predicted that the L1 speakers would fare better than their L2 counterparts in terms of the completion of similes. This hypothesis proved to be false. Both groups were able to produce plausible answers and the number of accurate answers supplied by each group hardly differed. This indicates that the participants (of both groups) were in fact able to produce similes although they did not necessarily know the standard version of the similes in question.

In sum, there were no statistically significant differences in the accuracy of the comprehension of Afrikaans idioms and the completion of Afrikaans similes by typically developing L1 and L2 child speakers of Afrikaans. It was assumed that the L1 speakers would be more familiar with figurative language in their L1 than the L2 speakers would be in their L2, but this was found not to be the case. A possible reason for these results could be that it is not the amount of exposure to idioms or similes in the language of others which is the main factor influencing a child's figurative language skills, but rather extent to which the child has developed an awareness of the existence of figurative language use. In other words, if a child is not yet aware of the phenomenon that what is said is not necessarily what is meant, then exposure to figurative language will not necessarily aid in the development of his/her figurative language skills, because the child will give a literal interpretation to any idioms and similes to which he/she is exposed. Nevertheless, it is recommended that the frequency of use of figurative language in typical L1 and L2 environments be studied, as quality and quantity of input have been shown to have a significant influence on various aspects of language development (see, for example, Goorhuis \& Schaerlaekens, 2003); this might be the case for figurative language skills as well.

The fact that their were no statistical differences between the performance of the L1 and the L2 speakers has an implication for educational practice: It appears that the phenomenon of figurative language and the meaning of idioms and similes need to be taught explicitly, regardless of whether the child is an L1 or an L2 speaker. In the present study, the completion 
of similes was found to be easier than the comprehension of idioms, supporting the finding by Pretorius (1989: 22), Reynolds and Ortony (1980), and Seidenberg and Bernstein (1986) that similes are significantly easier to comprehend than other forms of figurative language. Furthermore, it appeared that providing an idiom in context (as opposed to providing a 'bare' idiom) aided the comprehension of such idiom, as also found by Cain et al. (2001) and Levorato et al. (1992). It is therefore recommended that teachers introduce similes before idioms, and that idioms are taught in context. The L2 speakers' translations of idioms did not aid their interpretations thereof. There are several plausible reasons for this, such as a general lack of proficiency in their still developing L2, a lack of familiarity with Afrikaans idioms in particular, or simply an inability to comprehend figurative language in general. Regardless of the reason, idiom translation by learners is unlikely to be of value during the teaching process.

This study aims to contribute to the body of knowledge on children's knowledge of figurative language. Unlike many other studies on this topic, a minority language (Afrikaans) was studied, and data were also obtained from non-L1 speakers with an L1 which is structurally and semantically similar to the L2. Future studies on this topic should include larger numbers of participants, girls, speakers of languages structurally and semantically less similar to the target language, and speakers from cultures that differ greatly from that of the speakers of the target language.

\section{REFERENCES}

ABKARIAN, GG, A JONES \& G WEST. 1992. Young children's idiom comprehension: Trying to get the picture. Journal of Speech and Hearing Research, 35:580-587.

ACKERMAN, B. 1982. On comprehending idioms: Do children get the picture? Journal of Experimental Child Psychology, 33:439-454.

BURBULES, NC, G SCHRAW \& W TRATHERN. 1989. Metaphor, idiom and figuration. Metaphor and Symbolic Activity, 4(2):93-111.

CACCIARI, C \& S GLUCKSBERG. 1991. Understanding idiomatic expressions: The contribution of word meanings. In Simpson, GB (Ed.), Understanding word and sentence. Amsterdam: Elsevier.217-240.

CAIN, K \& JV OAKHILL. 1999. Inference making and its relation comprehension failure. Reading and Writing, 11:489-504.

CAIN, K, JV OAKHILL, M BARNES \& P BYRANT. 2001. Comprehension skill, inferencemaking ability and their relation to knowledge. Memory and Cognition, 29:850-859.

CAIN, K, JV OAKHILL \& K LEMMON. 2005. The relation between children's reading comprehension and their comprehension of idioms. Journal of Experimental Child Psychology, 90(1):65-87.

COOPER, C. 1999. Processing of idioms by L2 learners of English. TESOL Quarterly, 33(3):233-262. 
DOUGLAS, JD \& B PEEL. 1979. The development of metaphor and proverb translation in children grades 1 through 7. Journal of Educational Research, 73:116-119.

DURGUNOGLU, A \& B ÖNEY. 2000. Literacy development in two languages: Cognitive and sociocultural dimensions of cross-language transfer. A research symposium of high standards in reading for students from diverse language groups: Research, practice and policy. US Department of Education (Office of Bilingual Education and Minority Language Affairs, Washington DC.

GIBBS, RW. 1987. Linguistic factors in children's understanding of idioms. Journal of Child Language, 14:569-586.

GIBBS, RW. 1991. Semantic analyzability in children's understanding of idioms. Journal of Speech and Hearing Research, 34:613-620.

GIBBS, RW. 1994. The poetics of mind: Figurative thought, language, and understanding. New York: Cambridge University Press.

GIBBS, RW. 2002. A new look at literal meaning in understanding what is said and implicated. Journal of Pragmatics, 34:457-486.

GIBBS, RW, JM BOGDANOVICH, JR SYKES \& DJ BARR. 1997. Metaphor in idioms comprehension. Journal of Memory and Language, 37:141-154.

GIBBS, RW \& N NAYAK. 1991. Why idioms mean what they do. Journal of Experimental Psychology, 120:93-95.

GIBBS, RW, N NAYAK \& C CUTTING. 1989. How to kick the bucket and not decompose: Analyzability and idiom processing. Journal of Memory and Language, 28:576-593.

GIORA, R. 1997. Understanding figurative and literal language: The graded salience hypothesis. Cognitive Linguistics, 8:183-206.

GIORA, R. 2002. Literal vs. figurative meaning: Different or equal? Journal of Pragmatics, 34:487-506.

GOORHUIS, SM \& AM SCHAERLAEKENS. 2003. Handboek taalontwikkeling, taalpathologie en taaltherapie bij Nederlandssprekende kinderen [Handbook of language development, language pathology and language therapy of Dutch-speaking children]. Utrecht: De Tijdstroom.

GORDON, WJJ. 1961. Synectics. New York: Harper \& Row.

GRICE, HP. 1975. Logic and conversation. In Cole, P \& J Morgan (Eds), Syntax and semantics Volume 3: Speech acts. New York: Academic Press.41-58.

HASHEMIAN, M \& MRT NEZHAD. 2006. The development of conceptual fluency \& metaphorical competence in L2 learners. Linguistik online 30:41-56. Available online: http://www.linguistik-online.de/30_07/hashemianNezhad.html. [Accessed 14 July 2008]. 
HOFFMAN, R \& RP HONECK. 1980. Cognition and figurative language. Hillsdale, NJ: Erlbaum.

KATZ, AN \& TR FERRETTI. 2001. Moment-by-moment reading of proverbs in literal and nonliteral contexts. Metaphor and Symbol, 16:193-221.

LAUFER, B. 2000. Avoidance of idioms in a second language: The effect of L1-L2 degree of similarity. Studia Linguistica, 54(2):186-196.

LEVORATO, MC \& C CACCIARI. 1995. The effects of different tasks on the comprehension and production of idioms in children. Journal of Experimental Child Psychology, 60:261-283.

LEVORATO, MC \& C CACCIARI. 1999. Idiom comprehension in children: Are the effects of semantic analysability and context separable? European Journal of Cognitive Psychology, 11:51-66.

LEVORATO, MC, B NESI \& C CACCIARI. 1992. Children's comprehension and production of idioms: The role of context and familiarity. Journal of Child Language, 19:415-433.

LEVORATO, MC, B NESI \& C CACCIARI. 2004. Reading comprehension and understanding idiomatic expressions: A developmental study. Brain and Language, 91(3):303-314.

MALGADY, RG. 1977. Children's interpretation and appreciation of similes. Child Development, 48(4):1734-1738.

MANNO, G. 1998. Language teaching and non-literal meaning of signs. Multilingua, 17(1):59-91.

MARTINEZ, FE. 2003. Exploring figurative language processing in bilinguals. The metaphor interference effect. Unpublished MSc thesis, Texas University.

NELSON, NW. 1998. Childhood language disorders in context. ( $2^{\text {nd }}$ edition). Boston: Allyn \& Bacon.

NIPPOLD, MA. 1991. Evaluating and enhancing idiom comprehension in languagedisordered students. Language, Speech, and Hearing Services in Schools, 22:100-106.

NIPPOLD, MA \& ST MARTIN. 1989. Idiom interpretation in isolation versus context. A developmental study with adolescents. Journal of Speech and Hearing Research, 32:59-66.

NIPPOLD, MA, C MORAN \& LE SCHWARZ. 2001. Idiom understanding in preadolescents. American Journal of Speech-Language Pathology, 10:169-179.

NIPPOLD, MA \& CL TAYLOR. 2002. Judgments of idioms familiarity and transparency: A comparison of children and adolescents. Journal of Speech, Language, and Hearing Research, 45:384-391. 
OWENS, RE. 2001. Language development. An introduction $\left(5^{\text {th }}\right.$ ed). Needham Heights: Allan \& Bacon.

PRETORIUS, A. 1989. Die Afrikaanse semantiese taalevalueringsmedium [The Afrikaans semantic language evaluation medium]. Pretoria: A. Pretorius.

REYNOLDS, RE \& A ORTONY. 1980. Some issues in the measurement of children's comprehension of metaphorical language. Child Development, 51:1110-1119.

SEIDENBERG, PL \& DK BERNSTEIN. 1986. The comprehension of similes and metaphors by learning disabled and non learning disabled children. Language, Speech, and Hearing Services in Schools, 17(3):219-229.

VOSNIADOU, S. 1987. Children and metaphors. Child Development, 58(3):870-885.

WASOW, T, I SAG \& G NUNBERG. 1983. Idioms: An interim report. In Hattori, S \& K Inoue (eds), Proceedings of XIIIth International Congress of Linguistics, Tokyo.102115.

ZEMPLENI, MZ, M HAVERKORT, R RENKEN \& L STOWE. 2007. Evidence for bilateral involvement in idiom comprehension: An FMRI study. Neuroimage, 34(3):12801290.

\section{BIOGRAPHIC NOTE}

Kristin van der Merwe has an interest in psycholinguistics, particularly in language acquisition by children with special needs. Frenette Southwood is a lecturer in the Department of General Linguisitcs at Stellenbosch University. She has an interest in developmental language disorders and in second language acquisition. Her email address is fs@sun.ac.za. 


\section{APPENDIX}

\section{Idioms}

Decontextualised idioms are given in (a), with the meaning in English given in italics. Idioms placed in context are provided in (b).

1(a) Hy is ' $n$ bobbejaan.

He is stupid or silly.

1(b) Jannie dink dat melk van Pick ' $n$ Pay af kom en nie van ' $n$ koei nie. Hy is 'n bobbejaan.

2(a) Sy is 'n agie.

She is inquisitive.

2(b) Elke keer as iemand vir Sannie iets sê, vra sy: 'Hoekom? Hoekom?' Sy is 'n agie.

3(a) Hy is in sy noppies.

He is happy.

3(b) 'n Seuntjie het baie presente gekry vir sy verjaarsdag, en nou is hy in sy noppies.

4(a) Geld groei nie op my rug nie.

Money does not come from nowhere. Money does not just appear.

4(b) 'n Seuntjie wil baie graag 'n baie duur speelding hê. Hy vra vir sy ma of sy dit vir hom sal koop. Toe skud sy haar kop en sê: 'Geld groei nie op my rug nie!'

5(a) 'n Appeltjie met iemand te skil hê.

To want to speak to someone about a serious matter.

5(b) My pa het uitgevind dat ek sy motor gestamp het. Nou het hy 'n appeltjie met my te skil.

6(a) Ek is nie onder ' $n$ kalkoen uitgebroei nie.

I am not stupid.

6(b) My broer sê vir my hy het eendag 'n pienk koei in ons tuin sien rondloop. Ek sê toe vir hom dat ek nie onder' $n$ kalkoen uitgebroei is nie.

7(a) Die hele dorp was in rep en roer.

The whole town was busy.

7(b) Die president van die land het 'n klein dorpie kom besoek en toe was die hele dorp in rep en roer.

8(a) Hy het die hasepad gekies.

He ran away.

8(b) Die seuntjie wou nie sy kamer aan die kant maak nie en toe sy ma met hom wou raas, het hy die hasepad gekies.

9(a) Ek kan slange vang.

I am very angry.

9(b) Die man se motor is gesteel en toe hy dit uitvind, sê hy dat hy kan slange vang.

10(a) Hulle bak en brou net soos hulle wil. 
They do exactly as they please.

10(b) Toe die ma uitgaan om inkopies te doen, los sy haar kinders by die huis. Toe die ma terugkom, sien sy die hele huis is 'n gemors. Toe sê sy vir die kinders: 'Julle bak en brou soos julle wil as ek nie hier is nie, né.'

11(a) Ons ry met Jan Tuisbly se karretjie.

To stay at home.

11(b) Een vrou sê vir die ander vrou: 'Oe, ons gaan lekker vakansie hou in Bloemfontein.' Toe sê die ander vrou: 'Oe nee, hierdie jaar ry ons met Jan Tuisbly se karretjie.'

12(a) As die kat weg is, is die muis baas.

In the absence of supervision or authority, others do as they please.

12(b) As my ma weg is, dan dink my broer hy kan vir my sê wat ek moet doen en dit maak my kwaad. Ek vertel dit toe vir my ma, maar sy lag en sê dat as die kat weg is, is die muis baas.

13(a) Slaan die spyker op die kop.

To reach the correct conclusion.

13(b) Pieter wou nie skool toe gaan nie. Hy jok toe vir sy ma en sê sy maag is seer. Later praat sy ma met sy pa. Sy sê: 'Moes Pieter nie vandag daardie groot Wiskundetoets skryf nie? Mmm ... so hy is miskien nie siek nie ... hy wil net nie die toets skryf nie.' Die pa sê: 'Ek dink jy slaan die spyker op die kop.'

14(a) Sy skiet met spek.

She is telling a lie.

14(b) Chanel se ma sien hoe Chanel 'n lekkertjie steel. Chanel sê toe sy het nie 'n lekkertjie gesteel nie. Haar ma sê toe: 'Chanel, jy skiet met spek.'

15(a) Slaan voet in die wind.

To run away.

15(b) Die dief is in die bank. Skielik hoor hy die polisiesirenes en toe slaan hy voet in die wind.

16(a) Agteros kom ook in die kraal.

To eventually complete a task.

16(b) Uiteindelik het ek my werk klaar gemaak. Toe sê die onderwyseres vir my: 'Agteros kom ook in die kraal.'

17(a) Sy draai almal om haar vinger.

She easily manipulates people.

17(b) Een oggend vra 'n dogtertjie vir 'n lekkertjie van haar oupa, en hy gee toe vir haar een. Daardie middag vra sy haar pa vir 'n pop, en hy koop vir haar een. Daardie aand vra sy haar ma vir nog 'n stukkie koek, en haar ma gee dit vir haar. Toe sê haar oom vir haar ma: 'Die dogtertjie draai almal om haar vinger.'

18(a) 'n Kat in die sak koop.

To unknowingly have purchased broken merchandise.

18(b) My pa het vir my boetie 'n karretjie gekoop, maar hy het nie die boks in die winkel oopgemaak nie. Toe hy by die huis kom, sien hy dat die karretjie gebreek is. My ma sê hy moet dit na die winkel terug vat, want hy het 'n kat in die sak gekoop. 
19(a) Iemand oor die kole haal.

To reprimand someone.

19(b) Jannie skop aspris vir Sarel op die been. Die onderwyser sien dit. Toe het hy Jannie oor die kole gehaal.

20(a) Iets van die hand sit.

To sell something.

20(b) My pa het twee fietse gehad; toe besluit hy om een van die hand te sit.

21(a) Hy eet alles vir soetkoek op.

He is gullible.

21(b) As jy vir Jannie sê dat koeie kan vlieg, sal hy dit vir soetkoek opeet.

22(a) Lekker is maar 'n vinger lank.

When one is enjoying something, time passes very quickly.

22(b) Betty het 'n heerlike tyd by haar vriendin se partytjie gehad, maar toe moes sy huis toe gaan. Betty besef lekker is maar 'n vinger lank.

23(a) Die koeël is deur die kerk.

The damage has been done. Something is over and cannot be fixed.

23(b) Eendag was my broer kwaad. Toe breek hy aspris my ma se mooiste blompot. Toe voel hy sleg en sê vir my ma dat hy dit wil regmaak. Toe sê my ma die koeël is deur die kerk.

24(a) Die huis staan in ligte laaie.

The house is on fire.

24(b) Die Smit-familie het gaan uiteet. Oppad terug huis toe sien hulle brandweerwaens in hulle straat. 'Wat gaan aan?', vra mev Smit. 'Kyk,' sê mnr Smit, 'ons huis staan in ligte laaie!'

25(a) Aan iemand se lippe hang.

To listen attentively.

25(b) Die juffrou lees 'n baie opwindende storie vir die kinders en hulle hang aan haar lippe.

\section{Similes}

1. Iets is so groen soos... gras

2. Iets is so rooi soos... bloed

3. Iets is so stil soos 'n... muis

4. Iets is so wit soos... sneeu/wolke

5. Iets is so stadig soos ' $\mathrm{n} . .$. skilpad

6. Iets is so koud soos... ys

7. Iets is so maer soos 'n... kraai

8. Iets is so lig soos ' $n$... veer

9. Iets is so blind soos ' $\mathrm{n} . . . \mathrm{mol}$

10. Iets is so glad soos... seep

11. Iets is so dood soos 'n... mossie

12. Iets is so vinnig soos... blits 
13. Iets is so sterk soos ' $\mathrm{n} .$. leeu

14. Iets is so siek soos ' $\mathrm{n}$... hond

15 . Iets is so vry soos ' $\mathrm{n} .$. voël

16. Iets is so lelik soos die... nag

17. Iets is so taai soos ' $n$... ratel

18. Iets het weggeraak soos ' $n$... speld

19. Iets waggel soos ' $\mathrm{n} .$. eend

20. Hulle baklei soos... kat en hond

21. Hulle het geld soos... bossies

22. Iets pronk soos 'n... pou

23. Iets is so mak soos ' $\mathrm{n}$... hond/'n lam

24. Iets bewe soos ' $\mathrm{n}$... riet

25 . Iets is so doof soos ' $\mathrm{n} . .$. kwartel 